\title{
nature
}

31 May 2001 Volume 411 Issue no 6837

\section{Dangers of nationalism}

The drive to acquire intellectual property from research contributes to the wealth of nations, but can also undermine science if carried to excess. Exaggerated claims threaten to undermine the funding and climate of basic research.

$\mathrm{M}$ any countries around the world see the acquisition of patents stemming from research as a matter of national security and economic strength. Government leaders and some scientists view information technology and biomedical research as key competitive fields, and they push, with reformist zeal, towards application. But the hype surrounding the relationship between national strength and science has taken on an ominous tone that threatens to harm both basic research and scientific internationalism.

Many countries today see themselves trailing the United States in an intellectual-property race, and are looking for ways to catch up. Moreover, there are moves directed against isolated scholars, who are cast as crusty conservatives pursuing projects to satisfy their own interest. Such researchers are criticized for failing to realize the potential applications, and for their lack of profit-oriented motivation.

For smaller or developing countries with less generous research budgets, the application imperative can be stultifying. Some Chinese researchers, for example, complain about their inability to get funding unless they have a good 'gimmick' to sell. They rightly worry that funding will increasingly depend on demonstrable application, while more technologically modest but scientifically notable projects are shelved.

Will good basic research end up being overlooked? One of the enthusiastic leaders of Japan's movement towards application warns: "We could very well look back in 50 years and say we've made a huge mistake. But now it is the right thing to do - if done with care."

Certainly, Japan is trying to create a moral imperative out of money-making. The push into technology licensing and the restructuring of government research organizations (see Nature 410, 7; 2001) are geared towards making science more accountable to society and more profitable to researchers. They are also seen as preserving Japan's industrial strength — to some researchers in the vanguard, a lack of practical results means a waste of public money.
Still, much of this reform is just talk. Young revolutionary bureaucrats and technology-licensing promoters speak of radical change. Researchers write grant proposals in which they answer questions such as, "what benefit will your research have to society?". To a large extent, though, Japan continues to do a lot of good, basic research.

But even if bigger countries' basic research is protected from this latest phase of application-oriented reform, hype about intensifying industrial competition could restrict openness and thereby threaten another ambition that Japan, like many other Asian countries, pursues: respect for its researchers and their full participation within the international scientific community.

Former Prime Minister Yoshiro Mori's claim that Japan will overtake the United States in information technology within five years sounds like a harmless jest, but such hype creates a potentially explosive atmosphere. The recent 'bio-spy' incident, in which the United States charged Japanese researchers accused of stealing material for studying Alzheimer's disease with espionage, shows that the United States is increasingly ready to escalate tensions in such matters. Instead of being an incident involving the actions of a couple of researchers, accusation fell on Japan, sending shock waves through the Japanese research community. The Japanese press obligingly presented the episode as an almost inevitable outcome of an international intellectual-property race. Japanese researchers are understandably starting to wonder if they will ever be welcome in US laboratories. And as one US researcher in Japan put it, "all of the sudden I was frighteningly aware that I was a foreign scientist".

Countries who recognize that applied science can underpin their strength and prestige must also be prepared to support basic research, and to sustain the internationalism that is so essential to it. That requires a judiciously light touch in responding to foreign technological competition.

\section{Europe's right approach to energy}

The attitude of US governments and oil companies will be bad for their businesses.

$\mathrm{B}$ efore last week's upheaval in US politics, big oil companies must have looked on their generous donations to George W. Bush's campaign as money well spent. Bush's energy plan, released the week before, called for more fossil-fuel power stations and the opening up of the Arctic National Wildlife Reserve for oil exploration.

The defection of Republican Senator James Jeffords looks likely to obstruct much of that (see page 510). But it is unlikely to change the attitudes of ExxonMobil and other US oil companies towards emissions reductions to ameliorate climate change. Their confident hostility is boosted by the lack of action by successive US administrations.

In Europe, the political climate is different. The European Union (EU), negotiating as a block at the Kyoto talks on combating climate change, appeared genuinely to want the agreement to work. Individual EU members have already begun legislating.
With further regulatory changes forecast, the European oil companies are moving to adjust their business models (see page 516). Sensing a future in which fossil fuels are not the dominant energy source, BP and Shell have invested in alternative sources such as solar and wind power. They have also pledged a $10 \%$ cut in greenhouse-gas emissions resulting from their operations, a target both say they will reach in the next few years.

This approach costs money now, but it will pay dividends as renewables become a bigger source of our energy. Fossil fuels cannot power the planet for ever, and the US companies should be trying to adapt. Without a strong lead from the US government, they look unlikely to change their ways. President Bush should recognize that his current approach will hurt more than just the environment. In the long term (and perhaps in the short term too, if consumer activists have their way), the US oil companies will also suffer. 